\title{
¿ES UN SONETO DE GÓNGORA TAMBIÉN UNA ALABANZA?
}

\author{
ÁNGEL LUIS LuJÁN ATIENZA \\ Instituto de la Lengua Española \\ CSIC - Madrid
}

Aristóteles ya dejó sentado, con buen criterio, que el verso y la medida no hacen la poesía ${ }^{1}$. Un tratado de ciencia natural no deja de ser un tratado porque esté en verso, lo mismo que un libro de Historia. En los tiempos actuales, un informe de gestión o una noticia periodística no dejarían de serlo si alguien tuviera el extraño capricho de ponerlos en verso ${ }^{2}$. Del mismo modo, un elogio o una felicitación, por estar en verso, no dejan de ser lo que son: testigo de ello las tarjetas de Navidad o de cumpleaños. Incluso si uno tiene las ínfulas de declarar su amor en verso, su declaración valdrá como tal. Estas situaciones, que ponen en evidencia su naturaleza ambigua al compaginar el cumplimiento de una función pragmática con el uso de un tipo de lenguaje que en principio parece ajeno a tal función, nos abocan a la pregunta inquietante: ¿son estas actividades lingüísticas listadas y otras similares, además, poesía?

El problema y el desafío que ha planteado desde siempre el conjunto de subgéneros que hoy día y a partir del Romanticismo agrupamos bajo el rótulo de «lírica» tienen su centro en esta cuestión. Hay que dilucidar, en primer lugar, qué criterio serviría para agrupar estos subgéneros bajo una

\footnotetext{
1 Esta idea es repetida por todos los autores de los siglos de Oro. Véase el artículo de Aurora EGIDO, «Las fronteras de la poesía en prosa», en Fronteras de la poesía en el barroco, Barcelona, Crítica, 1990, pp. 85-114.

2 Jonathan Culler nos muestra la operación (ya experimentada por Jean Cohen) de transformar una noticia periodística en un poema por el expediente simple de organizar el texto en líneas a la manera de versos (Structuralist Poetics. Structuralism, Linguistics and the Study of Literature, London, Routledge and Kegan Paul, 1975, pp. 161-162). El argumento de Culler dice así: «If one takes a piece of banal journalistic prose and sets it down on a page as a lyric poem, surrounded by intimidating margins of silence, the words remain the same but their effects for readers are substantially altered». Yo, sin embargo, no creo que esta operación no altere el material lingüístico y no creo, en consecuencia, que las palabras «permanezcan las mismas».
}

Rlit, LXV, 129 (2003), 31-58 
misma y única categoría literaria si el criterio formal (en este caso el verso) no es definitorio de literatura y ellos no contienen en principio imitación en el sentido en que lo hacen drama y narración; y en segundo lugar, y unido a ello, qué criterio usar para separarlos de los géneros de discurso no-literario que ellos (los subgéneros líricos) necesariamente implican por cuanto son actos de habla definidos, como la alabanza, petición, lamento fúnebre, etc. ${ }^{3}$. Mi intención en este artículo es abrir camino a una posible respuesta a estos interrogantes, lo cual pasa por estudiar el estatuto pragmático de la llamada poesía de circunstancias, que por situarse, en nuestra concepción moderna, en los márgenes de la literatura me parece que constituye la piedra de toque de los criterios que se puedan aventurar para definir la unidad del género; unidad que, ya adelanto, no existe sino es desde una determinación puramente formal de la lírica, debido a la neutralidad de este «archigénero» con respecto a las condiciones pragmáticas de su enunciación.

Me ha parecido pertinente, para llevar a cabo este estudio, centrarme, por tratarse de un ejemplo relevante, en el análisis de un soneto de Góngora, que es a la vez una verdadera alabanza y petición de favor ${ }^{4}$. Como el espacio de este artículo es limitado dejo pendiente para un trabajo posterior un estudio general del estatuto comunicativo de la obra de circunstancia de Luis de Góngora, es decir, aquella parte de su producción que funcionó o pudo funcionar en contextos discursivos reales, aunque aquí aludiré, al hilo del comentario, a la relación que establece el poema elegido con el resto de la obra «de ocasión» del poeta cordobés ${ }^{5}$.

\section{Poesía y Circunstancia}

\section{A DON CRISTÓBAL DE MORA}

Árbol de cuyos ramos fortunados las nobles moras son quinas reales, teñidas en la sangre de leales

\footnotetext{
${ }^{3}$ Tzvetan Todorov, Les genres du discours, Paris, Seuil, 1978, pág. 25: «Par exemple, une certaine poésie lyrique et la prière obéissent a plus de règles communes que cette même poésie et le roman historique du type Guerre et Paix».

${ }^{4}$ A partir de ahora citaré la obra de Góngora por la numeración de los poemas de la edición de Antonio CARREIRA, Obras completas, Madrid, Biblioteca Castro, 2000, 2 vols. Detrás de cada poema aparecerá en paréntesis el número que le corresponde en dicha edición.

${ }^{5}$ Sobre la poesía de circunstancias de Góngora puede verse un reciente artículo que se centra en la lírica funeral: Antonio Carreira, «Poesía de circunstancias: epitafios a la Duquesa de Lerma (1603)», en Gregorio CABEllo PoRRAS y Javier CAMPOS DAROCA (coords.), Poéticas de la metamorfosis. Tradición clásica, Siglos de Oro y modernidad, Universidad de Málaga, Universidad de Almería, 2002, pp. 321-342.
} 
capitanes, no amantes desdichados:

en los campos del Tajo más dorados y que más privilegian sus cristales, a par de las sublimes palmas sales, y más que los laureles levantados.

Gusano, de tus hojas me alimentes, pajarillo, sosténganme tus ramas, y ampáreme tu sombra, peregrino;

hilaré tu memoria entre las gentes, cantaré, enmudeciendo ajenas famas, y votaré a tu templo mi camino.

Según Robert Jammes, estamos ante el primer poema cortesano de Góngora ${ }^{6}$, el cual pudo entrar en contacto con Cristóbal de Mora, alto dignatario de la corte de Felipe II, en 1593 en su estancia en Madrid, cuando volvía de una comisión del Cabildo de Córdoba en Salamanca, y pudo, incluso, entregarle en mano el poema. El soneto constituye una alabanza y una petición de favor y se desarrolla según las técnicas propias de la poesía de los Siglos de Oro. Góngora nos deja así un testimonio poético del momento en que empieza a acariciar la idea de hacer carrera cortesana ${ }^{7}$. A pesar de todas las prevenciones que tengamos contra la poesía de corte, como las que demuestra Jammes, hay que reconocer que este soneto es uno

${ }^{6}$ Robert Jammes, La obra poética de Don Luis de Góngora y Argote, Madrid, Castalia, 1987, pp. 219-221. Este autor nos da los datos esenciales sobre el dedicatario: «hombre de confianza de Felipe II y miembro de su consejo privado, una de las figuras políticas más importantes del momento», y en nota a pie de página: «Cristóbal de Mora (o más bien de Moura, porque era portugués) había desempeñado un papel determinante en la anexión de Portugal a la corona española. Había contribuido también al alejamiento del duque de Lerma, cuya influencia sobre el futuro Felipe III parecía nefasta. Esta enemistad le valió una semidesgracia cuando, a la muerte de Felipe II, el duque de Lerma tomó la dirección del gobierno. En 1600 fue enviado a Lisboa y en 1607 se le ofreció el virreinato de Portugal. Ese mismo año fue hecho marqués de Castel Rodrigo y conde de Lumiares. Murió el 28 de enero de 1613 a los 85 años de edad». El soneto y la figura del político portugués han sido glosados también por Biruté Ciplijauskaité en su edición de los Sonetos de Góngora, Madison, The Hispanic Seminary of Medieval Studies, 1981, donde figura con el número 8 (págs. 108-109). Puede verse una lectura de este soneto en clave irónica en Anne J. Cruz, «Góngora's ironic laudatory stance in his sonnet 'A Don Cristóbal de Mora'», en Romance Notes, XXVI, 1, 1985, pp. 59-64.

7 A este propósito apunta Jammes: «No sabemos más sobre esta tentativa ni sobre los objetivos precisos que perseguía don Luis en ese momento; todo lo más podemos suponer, teniendo en cuenta la edad de Cristóbal de Mora (que murió el 28 de enero de 1613 a los 85 años), que este mismo ministro de Felipe II había tenido, sin duda, ocasión de proteger al tío de Góngora y que don Luis se proponía con este soneto heredar su protección» (op. cit., pp. 220-221). 
de los más logrados del autor, y así fue ensalzado por Salcedo Coronel y Gracián, como veremos. El problema, entonces, estriba en articular una lectura que dé cuenta de su funcionamiento como tal discurso pragmático y a la vez como texto literario que hoy todavía se comunica con nosotros de manera relevante.

Que el poema realiza la alabanza de Don Cristóbal como un paso previo para solicitar su favor está fuera de toda duda, y que es el propio Góngora el que realiza tal acto discursivo también, aunque para ello establece un desplazamiento de la fuente enunciativa, como veremos ${ }^{8}$. Y aunque el autor no aparezca nombrado como tal dentro del poema, el hecho de dirigirse a un individuo sumamente conocido en su época individualiza, por reflejo, la voz que lo canta. Además está la propia imagen que el hablante del poema arroja de sí como poeta y cantor en los tercetos. Incluso aunque el soneto no tuviera título, la inscripción del nombre propio del alabado en el texto como parte del juego lingüístico sobre el que se monta el soneto (Mora / moral), indicaría que funciona en un ámbito de realidad.

Pero no debemos olvidar que hay un protagonista más en este intercambio lingüístico: el público lector. Góngora no hace una petición privada a través de un memorial o mediante una comunicación personal, sino que escribe un soneto, que a la vez que constituye un género reconocido socialmente (literario, en este caso), establece una comunicación por escrito. Esto es importante porque desde el momento en que un autor decide escribir un poema abandona la esfera de lo privado para inscribir su enunciado en un ámbito público no sólo en el sentido horizontal de contemporaneidad sino en el vertical de perdurabilidad en el tiempo, debido al carácter estable y permanente de la escritura. De esta manera, entendemos que la actividad discursiva concreta que tiene lugar a través de la escritura de este soneto es, no una mera alabanza y petición de favor, sino que hay que añadir a éstas su carácter público, el cual, en este caso, funciona de una doble manera: por una parte la alabanza lo precisa, ya que el hombre de estado necesita de tales muestras de exaltación expresa para sentir con-

\footnotetext{
${ }^{8}$ Entiendo por emisor el autor real del poema, mientras que la fuente es aquella entidad a la que se responsabiliza, en última instancia, del enunciado, y que en los géneros escritos es el «yo-hablante» al que accedemos directamente. Tomo esta distinción J. Verschueren, Understanding Pragmatics, London, Arnold, 1999, pp. 77-82. Véase a este respecto también Jorge LOZANo, Cristina PEÑA-MARín y Gonzalo ABRIL, Análisis del discurso: hacia una semiótica de la interacción textual, Madrid, Cátedra, 1993, p. 116: «Llamaremos locutor simplemente al emisor material de un texto y enunciador al autor textual, tal como lo hemos ido perfilando, definido por su enunciado también como responsable de los actos ilocucionarios que realice y susceptible de representarse de modos diversos y hasta contradictorios, de adoptar diferentes máscaras, o más bien de constituirse a través de los papeles que pueda asumir»; y el libro de M. M. GARCía NEGRONI y M. TORDESILlas COLADO, La enunciación en la lengua. De la deixis a la polifonía, Madrid, Gredos, 2001.
} 
solidado su puesto social; pero, por otra, la petición de favor convoca la publicidad como una estrategia para implicar a los lectores en el soneto e introducirlos como un elemento de presión en favor de la pretensión del autor. De esta manera, una audiencia, en principio anónima y general, es hecha entrar en el proceso de comunicación, y no sólo para hacer acto de presencia, sino que con ello se pone en un brete al noble elogiado ante la posibilidad de que sea todo un pueblo lector y toda la posteridad la que juzgue su actitud hacia el poeta.

Esta situación comunicativa no es diferente de los casos de comunicación simultánea a dos niveles que podemos encontrar en la vida ordinaria, por ejemplo en una entrevista televisiva a un político en que éste se dirige simultáneamente al periodista que formula las preguntas y al resto del país que constituye la audiencia. Una lectura de tesis supone una situación similar, y lo mismo se puede decir de las ceremonias de homenaje en que la alabanza personal al homenajeado va dirigida al mismo tiempo al público presente con el fin de que se sume al homenaje y dé su apoyo al conjunto de valores que encarna el homenajeado. De la misma manera, aquí el poeta se ve en la necesidad de desarrollar toda una serie de estrategias para garantizarse la adhesión del público, que resulta vital no sólo para que comparta los motivos de alabanza del noble sino para que respalde, con su asistencia, la petición de favor que lleva a cabo. Si el poeta consigue atraerse por completo al público (en el sentido retórico) y realiza bien su labor obliga al personaje elogiado a concederle el favor que pide, so pena de quedar en evidencia ante aquellos que leen. En consecuencia, el realizar una perfecta alabanza en el ámbito público tiene sentido principalmente en tanto que eso constituye una forma de atraer hacia el autor la voluntad del auditorio (sea oyente o lector). Que esta estrategia funcionaba lo sabe bien Góngora, que recibió un pingüe beneficio en pago de la serie de poemas realizados en honor de los marqueses de Ayamonte ${ }^{9}$, por no hablar de las relaciones de Lope con el Duque de Sesa o, en su correlato negativo, de la desgracia de Quevedo con el Conde Duque de Olivares.

Vemos, pues, que el carácter público del poema-alabanza-petición atrae e implica inmediatamente a un conjunto indeterminado de lectores que se constituye en juez inmanente de la habilidad del poeta para llevar a cabo su función y de la posible respuesta del alabado. Insisto ahora en que la audiencia que es hecha comparecer de esta manera no es sólo el contemporáneo de Góngora, que podía ejercer efectivamente una presión directa sobre Cristóbal de Mora, sino también nosotros, lectores del siglo XXI, que si bien ya no tenemos ninguna posibilidad de intervenir en aquellas relaciones sociales, sí somos receptores no sólo de la habilidad de Góngora en

9 Véase Dámaso Alonso, «Entre Góngora y el Marqués de Ayamonte: poesía y economía», en Obras Completas, tomo VI, Madrid, Gredos, 1982, pp. 153-170. 
su escritura sino también del nombre y figura de Cristóbal de Mora (la fama que se le promete en los tercetos) que posiblemente no hubiera llegado a nuestro conocimiento de no ser por el soneto de Góngora. En consecuencia, los lectores actuales estamos, con el mismo título que los contemporáneos, incluidos en la comunicación por cuanto las estrategias del soneto, en la medida en que es escritura, están pensadas para implicar a todo lector posible. En efecto, la escritura supone un paso primero y esencial en la desvinculación de la enunciación del entorno inmediato en que funciona, sobre todo cuando ésta es de alguna manera redundante, como ocurre aquí, es decir, cuando la escritura no tiene la función de superar una distancia, ya que, como hemos visto, Góngora podía haber recurrido a otro medio más inmediato e incluso oral para conseguir su propósito ${ }^{10}$. Se puede decir, entonces, que el hecho mismo de la escritura nos apunta a nosotros, lectores futuros: se pide a Don Cristóbal, pero se nos escribe a nosotros. Prueba de este poder de la escritura lo tenemos aquí mismo en las promesas del terceto final. Dichas promesas no contienen sólo su fuerza ilocutiva (lo cual es normal) sino que al mismo tiempo alcanzan su efecto perlocutivo gracias a la escritura, o dicho de otra manera, es una promesa que se autocumple. Cuando Góngora dice «hilaré tu memoria..., cantaré....», no lo promete sino que lo está cumpliendo en el momento en que lo leemos. El futuro es sólo una indicación lingüística del acto de habla de promesa, pero tal futuro se borra lógicamente porque es el presente de nuestra lectura.

Pero si este primer paso de desvinculación de un entorno pragmático concreto es necesario, no es suficiente, ya que esta desvinculación debe ir apoyada y complementada por otras estrategias enunciativas que hagan interesante y relevante realmente el enunciado fuera de ese marco pragmático que la escritura ayuda a superar. La escritura (como puro mecanismo) da el primer paso, el resto de las estrategias enunciativas deben confirmar que, en efecto, ese es el camino seguido. A este respecto hay que empezar diciendo que el soneto encanta, dentro y fuera del contexto pragmático en que nació, por su armonía. Aunque esta función incantatoria va profundamente unida a la necesidad de ganarse al público a la vez que constituye un indicio (en el sentido semiótico) del valor que se le supone al elogiado y que da lugar al desarrollo de tal armonía, está claro que destaca más y alcanza un valor más autónomo cuanto más nos alejemos del momento y ocasión que vio nacer al poema; de ahí que las lecturas posteriores (la

${ }^{10}$ Otra explicación posible es que se piense en el poema laudatorio como la forma más apropiada de vehicular la petición por el hecho de que el prestigio de la poesía hará más factible que el elogiado acepte el mensaje; más que si se le manda un memorial o se dirige a él de manera oral (forma esta última no siempre posible). Pero esta interpretación no contradice la mía sino que la refuerza, ya que si el elogiado se deja vencer por el prestigio de la poesía es porque está de acuerdo con el ambiente social que privilegia este tipo de escritura y cuenta con la lectura presente y futura del poema. 
historia de su recepción) se hayan centrado especialmente en ella. Testigo de ello son los comentarios que hicieron del soneto dos lectores privilegiados del XVII: García Salcedo Coronel y Baltasar Gracián. El primero nos dice: «Entre todos los sonetos de don Luis, ninguno hallo más digno de alabanza que éste... donde en metáphora de un Moral, con maravillosa amplificación alaba el generoso linage deste cavallero y solicita su favor, con frasis tan elegantes, con sentencias tan lúcidas, que pudiera este soneto hazerle grande entre los más famosos Poetas de la antigüedad» ${ }^{11}$. El comentarista no olvida la finalidad del soneto pero se centra principalmente en la manera de conseguirla, a través de la armonía y por medio de un despliegue lingüístico muy fino, que instala a Góngora entre los poetas de la antigüedad. Esto va a ser importante, porque una de las características de la enunciación de Góngora en muchos sonetos, y no sólo los celebrativos, es situarse como si enunciara desde la antigüedad y el paganismo ${ }^{12}$. De esta manera, la enunciación, permaneciendo anclada en la función de alabanza y petición, se desgaja de tal marco para situarse en un espacio superior de enunciación clásica intemporal, gracias precisamente a la ejemplaridad lingüística y armonía.

El comentario de Gracián insiste en la idea de armonía, pero más que desde un punto de vista puramente lingüístico, desde un presupuesto estructural señalando las consecuencias interpretativas del uso equilibrado de las imágenes que lleva a cabo el soneto: «Esta misma armonía y correlación hizo tan celebrado este soneto de don Luis de Góngora a don Cristóbal de Mora, marqués de Castel-Rodrigo [copia el soneto]. Va combinando sus empleos con el moral de su patrocinio, cantando ave o cisne a sus ramas, hilando como gusano de seda (que él dijo: hiló su cárcel) aliméntase de lo moral, y concluye, peregrino en sus soledades, votándole el camino. De suerte que esta primera especie de concepto consiste en una cierta armonía y agradable correspondencia, que dicen entre sí los términos, o con el sujeto» ${ }^{13}$. Gracián pone en primer término la armonía y la equilibrada correlación del soneto que hace de él un ejemplo de buen arte, independientemente de la función que cumpliera. Pero, además, Gracián implica que la coherencia y armonía que establece Góngora no sólo tiene que ver con el sujeto a quien se canta, sino que supone una inscripción del propio poeta en su poema, con lo que éste tiene una lectura alegórica o moral (moral en el sentido latino de «mores»: caracteriológica). Como explicaré después, Gracián alude aquí a la ocupación de Góngora como cantor (cisne), a una obra suya en que aparece el gusano de seda, y sobre todo a la gran creación de las Soledades, cuya figura central, el peregrino, Gracián

11 Apud JAMmES, op. cit., p. 219.

12 Piénsese en todos los sonetos amorosos de carácter pastoril.

${ }^{13}$ Baltasar Gracián, Agudeza y arte de ingenio, ed. Evaristo Correa Calderón, Madrid, Castalia, 1969, tomo I, p. 65. 
entiende como una figuración del propio autor. Vemos, pues, que la lectura de Gracián ya deriva hacia una interpretación de la alabanza como canto a sí mismo.

Las transformaciones imaginativas que lleva a cabo el poema, junto con su ejemplaridad lingüística, constituyen el engranaje para liberar al poema de su situación concreta y acceder a un plano simbólico en que la situación de enunciación se desdibuja y se universaliza. Empezamos por la transformación que el poeta hace sufrir al elogiado. Lo que puede parecer en principio un simple juego barroco con los nombres se convierte en una clave del funcionamiento de la enunciación. El alabado es convertido, por paronomasia, en el árbol de su propio nombre, en un moral, y de esta manera el poema garantiza a la vez el anclaje en una circunstancia concreta y su superación por medio de un sentido simbólico ${ }^{14}$, y en consecuencia sitúa la enunciación en el terreno concreto de la identificación personal y en el simbólico de la comunicación intemporal al mismo tiempo. Pero además, la transformación del nombre propio en símbolo sirve para desarrollar por amplificación todo el poema y construirlo en torno a esa idea central, lo que lo convierte en un todo coherente y en cierta manera autónomo, que por su propia fuerza centrípeta lo aparta de la comunicación pragmática inmediata, constituyéndose como un cosmos casi cerrado. A esto era a lo que aludía Gracián cuando hablaba de la correspondencia de las imágenes. Góngora usó con profusión esta técnica, que va desde el simple enmascaramiento del nombre propio bajo un pseudónimo (como Clori para referirse a la hija del Marqués de Ayamonte ${ }^{15}$ ), hasta los juegos más complicados como el que lleva a cabo con Soto de Rojas ${ }^{16}$ o con el obispo Mardones ${ }^{17}$, y a veces no con el nombre sino con la función del personaje, ya que por ejemplo el cargo de «pastor» de un obispo le autoriza para dirigirse a él como un pastor arcádico ${ }^{18}$.

Para fijar el significado de las transformaciones figurativas que lleva a cabo Góngora en este soneto, acudiré a las explicaciones que dan los libros de emblemas sobre las imágenes que el poeta usa ${ }^{19}$. Con ello no quiero

\footnotetext{
${ }^{14}$ Sobre la simbología arbórea de los Siglos de Oro y de este poema en concreto puede verse E. George ERDMAN, Jr., «Arboreal Figures in the Golden Age Sonnet», en PMLA, 84,3,1969, pp. 587-595.

15 Carreira (ed.), 174: «al sol peinaba Clori sus cabellos»; Carreira (ed.), 178.

${ }^{16}$ Carreira (ed.), 253. Aquí el juego se establece con «Soto» y flores «Rojas».

17 Carreira, (ed.), 447, v. 14: «un Mar, dones hoy a sus arenas»; Carreira (ed.), 301, v. 17: «mar de virtudes profundo».

${ }^{18}$ Carreira (ed.), 60.

19 Sobre Góngora y la emblemática pueden verse CiocchinI, Héctor, Góngora y la tradición de los emblemas, Bahía Blanca, Universidad Nacional del Sur, 1960; y PÉREZ LASHERAS, Antonio, «Imágenes emblemáticas gongorinas: la Fábula de Píramo y Tisbe», en Hommage à Robert Jammes, Toulouse, Presses Universitaires du Mirail, 1994, vol. III, pp. $927-938$
} 
decir que el lector necesite conocer estas explicaciones para entender el poema, aunque funcionaban efectivamente como horizonte interpretativo para los contemporáneos de Góngora. Lo que intento con ello es estudiar, de manera metarrepresentativa, cómo la elección, por parte de Góngora, de esas imágenes, con sus implicaciones, mimetiza el proceso mismo de enunciación que me propongo definir, aunque éste sigue siendo operante y el mismo independientemente de que se acceda a la metarrepresentación figurativa.

El moral simboliza la sabiduría y la prudencia, ya que espera a echar sus frutos cuando han pasado los hielos, y así da provecho tarde pero con seguridad $^{20}$. Son éstas virtudes valiosas en un hombre de estado, sin embargo, a primera vista, no son las galas con que Góngora viste a Mora en el soneto, que más bien se fija en el valor militar y la magnificencia de sus propiedades. Y es que la figura del moral interesa a Góngora para resaltar otro de sus sentidos, que se encuentra también en la literatura emblemática y que remite al proceso de creación artística ${ }^{21}$, con lo que la alabanza en principio dirigida al noble empieza a volverse hacia la tarea del escritor y su caracterización. El moral aparece, así, como símbolo del sabio y del escritor que meditando mucho da fruto tardo pero provechoso, y se opone por ello a los ingenios fervorosos, simbolizados por el almendro, que en-

${ }^{20}$ Véase la definición que da Sebastián de Covarrubias en su Tesoro de la lengua castellana (ed. Felipe C. R. Maldonado, rev. Manuel Camarero, Madrid, Castalia, 1994, p. 763): «MORAL. Árbol conocido, latine MORIUS; según algunos se dijo a mora, que vale tardanza, por ser de los árboles que más tarde echan, y a tiempo que ya no tienen

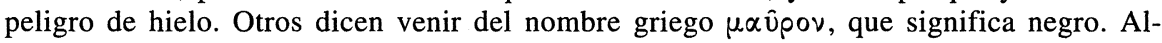
gunos quieren se diga de $\mu \omega \rho$ ós, latine stultus, per antiphrasim, por ser este árbol discreto y sabio, en esperar a que pasen los fríos para brotar y echar sus pimpollos cuando los hielos y fríos no le pueden ofender. Verás a Alciato, en el emblema 209, y sobre él sus comentadores Sánchez y Minoes. El emblema dice así, contraponiendo el moral al almendro que se apresura en florecer:

Serior et morus, numquam nisi frigore lapso

Germinat et sapiens nomina falsa gerit».

${ }^{21}$ Sebastián DE COVARRUBIAS, Emblemas morales, ed. Carmen Bravo-Villasante, Madrid, Fundación Universitaria Española, 1978 (es edición facsímil de la edición de Madrid, Luis Sánchez, 1610), recoge el de Alciato (que ya había citado en su Tesoro) «Sapiens nomina falsa gerit» (III,57) y lo glosa en los siguientes versos:

El moral como bobo es perezoso,

opuesto al antuviado almendro, y echa cuando ha pasado el tiempo riguroso,

y su fruto se goza y aprovecha.

El ingenio precoz y fervoroso

tras grande muestra danos ruin cosecha,

el tardo y manso vase poco a poco:

este es moral y el otro almendro loco.

Hago notar que cuando cito de Covarrubias y otros libros de emblemas modernizo la ortografía. 
seguida florecen pero cuyo fruto se echa a perder. El moral, por tanto, como símbolo doble, apunta por una parte al elogiado, y por otra al propio poeta, cuyo fruto (el poema trabajado y meditado) no se agota en el momento de la escritura (en este caso, como alabanza concreta) sino que será gustado más tarde y con mayor tranquilidad por los lectores futuros.

Pero, además, Góngora superpone aquí otro juego de asociaciones, y es que el árbol al que alude es también el «árbol genealógico», una de cuyas ramas o frutos será el noble alabado. Esta concentración de significados sirve igualmente como estrategia para incluir al lector en el poema, que se ve obligado a ir descubriendo y superponiendo significados al hilo de su lectura. Su labor tiene que ser reconstruir en el primer cuarteto un sentido que se puede glosar como: «La genealogía del elogiado está llena de nobleza, realeza y valerosos capitanes, por contraste con la genealogía falsa, mítica y pueril del moral que se hace proceder de la muerte de los amantes Píramo y Tisbe» ${ }^{22}$. De esta manera, con la distinción de los significados entrelazados y la aclaración de las alusiones mitológicas, el lector se convierte en cierta medida en coautor del poema, y se siente parte real de la construcción de sentido ${ }^{23}$.

Pero conviene no abandonar todavía la figura genérica del árbol, porque en la emblemática encontramos otras asociaciones con la labor de escritura y con la idea de muerte y renacimiento ${ }^{24}$. El árbol forma parte de

${ }^{22}$ Para las alusiones de este primer cuarteto remito a las notas de Biruté Ciplijauskaité (Castalia, 1985, p. 59): «las armas del reino de Portugal tienen cinco escudos azules puestos en cruz, llamados quinas reales» y «Alusión a Píramo y Tisbe, cuya muerte hizo que las moras adquirieran color morado, y contraponiéndola a la muerte heroica en el campo de batalla».

${ }^{23}$ Sabido es que Góngora estableció explícitamente la relación entre oscuridad poética y participación del lector (en el sentido de creación de su propio público) en la famosa carta en respuesta a otra anónima que le enviaron con motivo de la circulación de las Soledades (Carreira, tomo II, pp. 295-298): «y si la obscuridad y estilo intricado de Ovidio (...) da causa a que, vacilando el entendimiento en fuerza de discurso, trabajándole (pues crece con cualquier acto de calor), alcance lo que así en la letra superficial de sus versos no pudo entender luego, hase de confesar que tiene utilidad avivar el ingenio, y eso nació de la obscuridad del poeta»; y «Demás, que honra me ha causado hacerme obscuro a los ignorantes, que esa es la distinción de los hombres doctos, hablar de manera que a ellos les parezca griego, pues no se han de dar las perlas preciosas a animales de cerda». De esta manera, la oscuridad invita al lector a participar en lo docto del discurso del autor, y ser copartícipe de su ingenio.

${ }^{24}$ Aurora Egido habla también de la simbología del árbol: «Las mitologías orientales conferían al árbol la expresión de la inmortalidad en todo lo concerniente al mitema del árbol de la vida, tan ligado al Génesis. [...] Claro que, como afirma el propio Mircea Eliade, 'no hay que dejarse ofuscar por la riqueza casi ilimitada de las hierofanías vegetales', pues todo viene a dar en un significado común que engloba el resto, el de que la vida se regenera periódicamente» («Variaciones sobre la vid y el olmo en la poesía de Quevedo: 'Amor constante más allá de la muerte’», en Fronteras de la poesía en el barroco, pp. 220-222). 
un ciclo de constante muerte y resurrección que mimetiza el proceso de la comunicación por escrito que es letra muerta en el papel pero cobra vida cada vez que es leída por alguien. Un emblema recogido por Covarrubias y que tiene por motivo el árbol expresa bien esto, pues une la idea de la muerte y la resurrección cíclica de la naturaleza con la afirmación de Horacio en el Arte Poética sobre la vitalidad de las palabras con el lema: «Multa renascentur quae iam cecidere» ${ }^{25}$, que Horacio aplica a la renovación de los arcaísmos. En otro emblema de árbol, cuyo lema reza: «Si post fata venit Gloria, non propero», vemos que la gloria sólo se alcanza a través de la muerte (la corona está reservada para los desaparecidos), o dicho de otra manera, el autor tiene que morir para vivir en las palabras ${ }^{26}$.

En el desarrollo amplificativo que Góngora lleva a cabo en el soneto, el moral se opone, en el segundo cuarteto, a dos tipos de árboles, en este caso superándolos: el laurel y la palma, con lo cual se invita al lector a desplegar todo lo que conoce sobre ellos, es decir, activa nuevamente una lectura simbólica. Del laurel no hace falta hablar como símbolo literario. En cuanto a la palma, podría pensarse que la dicotomía «palma / laurel» sirve para movilizar la dicotomía victoria «militar / poética» haciendo que el elogiado sobresalga en todos los campos: armas y letras. Sin duda este tópico está detrás de la lectura del poema, pero la palma, además, moviliza un sentido literario que está en relación con la permanencia y la posteridad de los frutos del escritor, pues los frutos de la palma no los disfruta quien la plantó sino sus descendientes. En el emblema 59, centuria I de Covarrubias, leemos el mote «Factura nepotibus umbram», y en el dibujo aparece una palmera junto a un edificio en construcción. El texto no es importante, pero sí la glosa que nos habla de que debemos obrar de mane-

${ }^{25}$ HoRACIO, Arte poética, v. 70. Covarrubias, ed. cit., centuria I, emblema 77. El grabado presenta un árbol del que caen semillas y a cuyo pie brotan nuevos árboles. El texto dice:

Aquello que ora es, antes ha sido

$\mathrm{Y}$ ha de volver a ser lo que es agora,

Y así remozará lo envejecido,

Mudando lo presente de hora en hora.

No hay cosa que no haya acontecido

$\mathrm{Ni}$ novedad de espanto causadora.

Ese nuevo es renuevo de la planta

Que cae en tierra y de ella se levanta.

${ }^{26}$ Covarrubias, ed. cit., Centuria II, emblema 2. El dibujo presenta un árbol a cuyos lados una mano descarnada agarra una corona verde y una mano de persona viva agarra una corona seca. La glosa nos dice: «Ordinaria cosa es reverenciar y estimar los que tuvieron algún nombre en los pasados siglos y hacer poco caso de los que viven y concurren con nosotros en un tiempo. Porque a los unos engrandece la antigüedad y a los otros apoca la invidia (...). Para significar esto pongo un brazo descarnado con solos los huesos y una corona verde, otro brazo con carne como de persona viva con una corona seca». 
ra que igual que a nosotros los antepasados nos han legado sus bienes nosotros actuemos para dejar cosas útiles a nuestros sucesores: «La palma dicen ser una planta que en cien años no da fruto y ansí el que la plantare ha de hacer cuenta que los venideros le han de gozar por él, lo mesmo es de los edificios y de todo lo demás que se perpetúa» ${ }^{27}$. Podíamos decir lo mismo de la poesía.

Vemos, pues, que todas las imágenes empleadas hasta ahora tienen una doble dirección, por una parte se dirigen hacia la alabanza del elogiado, y por otra se dedican a retratar el tipo de comunicación que tiene lugar en el poema, en tanto que la labor del poeta consiste en trabajar y en morir simbólicamente para que sus palabras vivan y aprovechen más allá de su inmediata producción. La capacidad inmortalizadora de la palabra escrita, la palabra poética, que es de lo que aquí en definitiva se trata, está íntimamente ligada a la función de alabanza, que tiene como fin perpetuar en la memoria futura al alabado. Con ello se está poniendo en primer plano o al menos se está dando una pista sobre la lectura del poema de alabanza como una autoalabanza en realidad del poder del poeta para proyectar su imagen y la de cualquiera que elija por encima de su transitoria temporalidad, abriendo así la enunciación a todo futuro posible.

Esto no hace más que preparar el terreno para el verdadero acierto del soneto que son las transformaciones metafóricas que de sí mismo hace el poeta en los tercetos, con la perfecta correlación que les da toda su fuerza. Si el alabado es transformado en moral, símbolo de humildad y de prudencia y ensalzado sobre las palmas y laureles, el poeta tiene que buscar una transformación acorde con este estado. Y encuentra tres que son, correlativamente al ensalzamiento del noble, símbolos de humildad: gusano de seda, pajarillo y peregrino; tono humilde que, desde luego, requiere el acto de petición de favor. Pero hay que observar que frente a una única transformación del alabado, el poeta se destaca numéricamente por tres transformaciones, más originales que la contraposición entre los árboles. Además, como ya señalaba la cita de Gracián, estas transformaciones sirven para inscribir al propio poeta en su enunciado, no sólo bajo los sím-

\footnotetext{
27 Otro emblema, el 45 de la segunda centuria insiste en la tardanza de la palma en dar fruto como imagen de las grandes cosas que se emprenden y que deben llevar su tiempo en madurar, bajo el lema: «Nil magnum longo nisi tempore». El dibujo presenta un elefante y una palma y se lee en el texto:

Si el alma concibió un gran sujeto

Maravilla no es que el parto tarde

Siéndole necesario estar secreto

Y que sazón y tiempo y orden guarde:

Un elefante no nace perfeto

De un año ni aún de dos, y nadie aguarde

El fruto de la palma tan temprano

Como será del pero o del manzano.
} 
bolos tradicionales y genéricos del cisne que canta (y nótese que Góngora dice sólo «pajarillo») y de su labor de dar una lectura moral de la realidad, sino también más personalmente poniendo esta obra en relación con otras obras del autor y principalmente en relación con las Soledades, pues Gracián entiende que este peregrino del soneto es una prefiguración del protagonista de la gran obra de Góngora. Según esto, este singular poema contendría en sí toda la obra de Góngora, y la armonía que lo hace, en cierta manera, autónomo y capaz de despegarse de su situación concreta estaría al servicio de una armonía mayor que es el cosmos de la obra de Góngora, cuyo personaje principal es el propio autor transformado en pajarillo cantor («cisne», según Gracián), en gusano que hila su propia cárcel donde queda enterrada su identidad y en peregrino que atraviesa este mundo moral creado por la obra ${ }^{28}$.

Antes de entrar propiamente en el análisis de las implicaciones de estas figuraciones quiero hacer notar que la triple transfiguración del poeta se produce gracias a un fenómeno puramente lingüístico constituido por el hecho de que la escritura permite una mayor libertad al establecer las relaciones entre emisor y fuente, por el simple hecho de que en un escrito (frente a un intercambio oral) accedemos directamente a una fuente de enunciación y en última instancia a un emisor, que en algunos casos incluso puede quedar sin determinar (anonimia). De esta manera, el emisor real Góngora, que elude su presencia física al dar su comunicación al medio escrito, tiene una mayor libertad para adoptar distintas formas de aparecer (fuentes) en su poema. Estas transformaciones figurativas funcionan, al igual que la del nombre del alabado, como índice de un despegue de la situación real de emisión hacia un ámbito de significados y enunciaciones simbólicas de carácter intemporal. O dicho de otra manera, el emisor se proyecta como fuente a un mundo enunciativo simbólico, y de manera triple, además, con lo que ello supone de desubicación y de multiplicación de la identidad en aras de la búsqueda de un sentido más allá de la puntual alabanza y petición de favor.

Empezaremos, pues, por la figura del gusano de seda, primera trans-

${ }^{28}$ La fama como el principal fin de los poetas aparece en Luis CARRILlO Y SOTOMAYOR, Libro de la erudición poética, en Obras, ed. Rosa Navarro Durán, Madrid, Castalia, 1990, p. 345: «Pues así es, que éstos (mediante el modo de escribir usado dellos) alcanzaron el fin último de los poetas, que es la fama; luego, todos los que siguieren sus pisadas de la suerte que ellos, tendrán igual fama con ellos». El intento de glorificación de uno mismo a través de una aparente alabanza a otro está presente en el fondo de este poema y ha sido bien visto por Anne J. Cruz en el artículo citado, p. 64: «What appears to read as a typical laudatory poem addressed to a potential patron results instead in an ironic warning that the recipient had better avail himself of the poet's service for his own good. The innocent and humble metaphors of worm, bird, and pilgrim belie a poet who would not hesitate to exercise his talent to his own advantage and at the expense of his patron». 
formación imaginativa del poeta. A pesar de su pequeñez este insecto da lugar a muchas lecturas morales, como señala Covarrubias ${ }^{29}$, incluso contradictorias, según deja patente un recorrido por la emblemática. Por una parte es símbolo del hombre que se dedica al estudio y sacrifica su vida para crear algo bello y provechoso, y como tal aparece en el emblema 59 de la tercera centuria de Covarrubias, que lleva por lema: «Fin che io finisca», y cuyo texto dice:

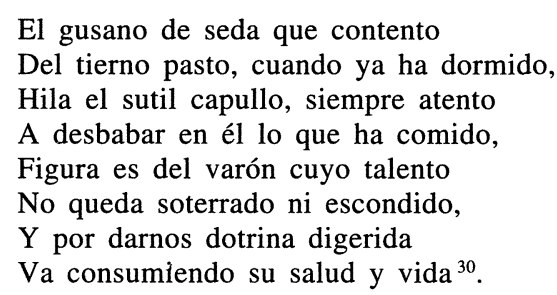

Pero encontramos también la lectura contraria, en la que el gusano figura al hombre que peca de sutilidad y de gastar demasiado ingenio en cosas que no son de provecho. Así, en un emblema de Juan de Horozco y Covarrubias aparece en competencia con la araña que hila para su provecho, mientras que el gusano lo hace gratuitamente: «el gusano de la seda... representa los cortesanos, que se precian de muy discretos... la araña... representa la parte de los que... se pasan sin estas sutilezas, y atienden a solo lo que les conviene sin tratar de esos primores» ${ }^{31}$. Vemos con esto

${ }^{29}$ CovarRubias, Tesoro, ed. cit., p. 615: «Hay muchas diferencias de gusanos, y en la consideración dellos, siendo tan tristes animalejos, hay mucho que considerar en su naturaleza, pues los que crían la seda, dichos en latín bombices, nos dan tanta riqueza y gala, sacando de sus entrañas el capullo de seda, labrando su sepulcro, pues al cabo se quedan encerrados en él y mueren; el volver a nacer del gusano muerto una palomita o mariposa, que con su simiente vuelve a renovar el gusano, que sale o cría della, de cuya especulación se sacan altísimos conceptos».

${ }^{30}$ La glosa también es interesante: «como el edificar, dicen, que es un dulce empobrecer, así el estudiar y ocuparse en letras es un dulce morir, que sin sentirse va consumiendo la virtud natural, bien como si muriese desangrado en el baño de agua caliente».

${ }^{31}$ Véase Antonio BERnAT VISTARINI y John T. CUlL, Enciclopedia de emblemas españoles ilustrados, Madrid, Akal, 1999, núm. 763. En el mismo contexto van otros emblemas que vemos recogidos en esta enciclopedia:

$$
\begin{aligned}
& \text { De su propria sustancia aquel gusano } \\
& \text { artífice ingenioso de la seda } \\
& \text { va texiendo un capullo do se enreda, } \\
& \text { y muere en cárcel hecha por su mano. } \\
& \text { De solo esto sirvió el trabajo vano } \\
& \text { a él, mas otro al fin lo desenreda } \\
& \text { y dispone de suerte que se pueda } \\
& \text { honrar con ello el noble cortesano. } \\
& \text { ¡O duro afán o desventura fuerte } \\
& \text { morir por tener algo y no gozallo, }
\end{aligned}
$$


que el gusano viene a simbolizar a la vez al poeta industrioso y al cortesano de sutilezas ociosas (¿alabador y alabado ${ }^{32}$ ), y ambas interpretaciones parten de un mismo hecho: que el gusano teje preciosamente su propia muerte para no aprovecharse de ello, lo cual puede verse como símbolo de la inutilidad y trivialidad o de la generosidad.

El poema de Góngora al que alude Gracián en la cita que hemos visto, es un romance (231) donde precisamente se pone de manifiesto la futilidad y esterilidad de preocuparse por los demás, y es en el fondo una autocrítica por la generosidad. Comienza así:

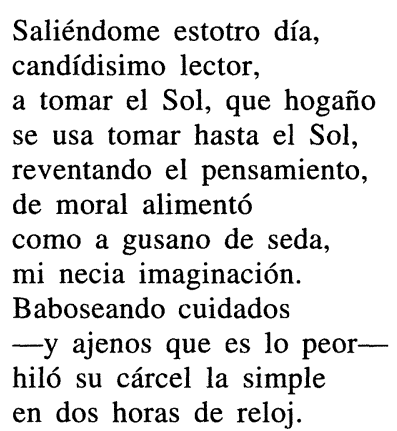

Asistimos aquí al mismo juego del pensamiento alimentándose del sentido moral, que le sirve para encerrarse en su propia cárcel a través de la imagen de «babosear cuidados» (al hilo del gusano se le llamaba entonces «baba»). El romance lo que propone, en definitiva, es romper esta prisión hecha de «ajenos yerros», y establecerse uno mismo como objeto de su propia preocupación con una defensa final del «yo» bastante acusada:

En este capullo estuvo
el juïcio de don Yo

para que otro se goce con su muerte!

$¡ O$ quántos ay con sedas y a cavallo

a quien dexó en estofa y buena suerte

la miserable del que fue en ganallo!» (núm. 766).

32 En los tercetos «Mal haya el que en señores idolatra» (202) puede haber una referencia al gusano de seda (vv. 34-39):

Guardad entre esas guijas lo risueño

a este dómine bobo, que pensaba

escaparse de tal por lo aguileño, celebrando con tinta, y aun con baba,

las fiestas de la corte, poco menos

que hacérselas a Judas con octava.

Apunto aquí, sin desarrollar, la idea de la contraposición entre la labor generosa del poeta Góngora, y la «baba» cortesana de Don Cristóbal de Mora, que iría incluso más allá de la interpretación irónica que hace Anne J. Cruz en el artículo citado. 
dos horas: lector, «a Dio»

que en bergamasco es «a Dios» ${ }^{33}$.

A la luz de este dato podemos empezar a entender la alusión al gusano en el soneto como un intento de superar la imagen de humildad extrema que parece presentar en una primera aproximación, y mostrar la labor del hilado del gusano como una afirmación de la propia labor del escritor y de una proyección fuerte del «yo» en la escritura. Pero esta lectura que propongo quedará más clara cuando veamos cómo Góngora relaciona la imagen del gusano con la del mito de resurrección por excelencia (y uno de los predilectos del cordobés): el del Ave Fénix. Recordemos un pasaje del romance «Diez años vivió Belerma» (28):

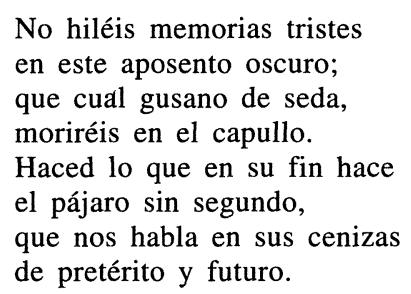

Aquí, al gusano de seda que muere dentro de su capullo para transformarse en crisálida resulta comparable con el proceso de muerte y resurrección del Fénix. Curiosamente, Góngora usa aquí la misma expresión que en el soneto: «hilar memorias», pero mientras que las del romance son tristes, las que se propone hilar en el soneto miran hacia el futuro y se emparentan con el renacer del Fénix. Así, el poeta se presenta como un humilde gusano que renacerá en memoria futura como el Ave Fénix, lo que constituye el mito de la escritura en cuanto enunciación, a que apuntaban también las imágenes anteriores: la comunicación escrita muere en la ocasión precisa en que cumple su función para volver a renacer esplendorosamente en cada momento futuro en que se lea el poema ${ }^{34}$.

Encontramos otros testimonios de la relación entre el gusano y el Fénix en la obra de Góngora, como en la Soledad Primera, versos 737-742:

Este, pues, Sol que a olvido lo condena, cenizas hizo las que su memoria

${ }^{33}$ El uso de este «yo» burlesco está también en una carta (Epistolario, 38): «El catarro del amigo holgaría que se hubiese reparado con las sangrías, puesto que las tengo por superfluas donde andan tales sanguijuelas como Antonio de Poma y don Luis de yo».

${ }^{34}$ Quiero hacer notar que el ave Fénix es la figura elegida por Góngora para designar a los monarcas. Véase Carreira (ed.), 161: «el nido venerad humildemente / del Fénix hoy que reinos son sus plumas» (vv. 11-12), y los números 266, 267, 356, 398 (el recuento no es exhaustivo). De esta manera, el poeta parece asumir la naturaleza de la realeza: es un ser único (como el Fénix) que puede desaparecer como individuo pero que se perpetua como figura de poder. 
negras plumas vistió, que infelizmente sordo engendran gusano, cuyo diente, minador antes lento de su gloria, inmortal arador fue de su pena.

$\mathrm{Y}$ es que, según anota Salcedo Coronel en un pasaje anterior de las Soledades: «[El ave Fénix] cuando envejece hace un nido de ramos de canela y de incienso y llenándole de cosas olorosas puesta sobre él se muere, y de sus huesos y medulas nace un gusanillo de que se forma después una nueva fénix» ${ }^{35}$. En el pasaje de las Soledades citado tenemos sólo la primera parte del proceso: las cenizas producidas por el ave engendran un gusano que en lugar de renacer se convierte en el gusano que roe (el gusano de la conciencia). Y algo similar encontramos en otro soneto de circunstancias, el dedicado al sepulcro de la Duquesa de Lerma (134), cuyo primer terceto dice:

\section{La Fénix que ayer Lerma fue su Arabia es hoy entre cenizas un gusano, \\ y de consciencia a la persona sabia.}

La editora anota al respecto que el gusano se contrapone al Fénix porque «contrariamente a lo que acontece con el ave, el cuerpo de la Duquesa ya empieza a pudrirse» ${ }^{36}$, pero creo que lo que hace aquí Góngora en realidad es apuntar, no a la descomposición del cuerpo de la Duquesa (cosa que resultaría sorprendente) sino a su posible resurrección a manera de ave Fénix ${ }^{37}$, a la vez que el gusano debe avisar a la conciencia del resto de los mortales. En este sentido, el gusano es «moral» en cuanto dicta el contenido de la conciencia. Con todo ello, tenemos en la figura del gusano una constelación completa de significados que giran en torno a la labor del poeta y la comunicación poética. El poeta se alimenta de la interpretación moral de su propia alabanza para engendrar un poema que a la vez que lo encierra en una forma rígida y en una acción concreta (alabanzapetición) garantiza su inmortalidad para el resto de los lectores futuros. La memoria que hila el poema es el rescate de la enunciación cada vez que un lector se acerque a él. El poema instaura memoria, y la perfección del soneto garantiza que la posteridad sabrá tanto de la figura del alabado como de la del artífice.

Pajarillo es la imagen del cantor, que Gracián sobreinterpretando asi-

${ }^{35}$ Tomo la cita de Antonio CARreIRA, en su Antología poética de Góngora, Madrid, Castalia, 1986, p. 221.

${ }^{36} \mathrm{Me}$ refiero a Biruté Ciplijauskaité, pero no en la edición citada de los sonetos, sino en la de Madrid, Castalia, 1985, donde este soneto aparece con el número 132.

${ }^{37}$ De hecho, el siguiente soneto con el mismo asunto (135) insiste en el buen olor del sepulcro de la dama, en relación con las resinas aromáticas entre las que ardía el Fénix. 
mila con el cisne, imagen más habitual para el poeta. De la misma manera que en la figuración anterior, aquí la humildad inicial que supone el empleo del diminutivo viene desmentida por la hipérbole de la función del poeta que se arroga un poder especial, el de enmudecer las famas de otros. Incluso puede que haya una referencia al deseo de superación de la sonoridad de otros géneros bélicos y de las trompetas épicas con que habitualmente se pinta a la fama. Y es que después de la lectura del símbolo anterior no puede dejar de resonar, cuando hablamos de pájaros, no sólo el canto del cisne sino el mismo Ave Fénix. A la vez, el pájaro se asocia con la figura del escritor en un sentido especialmente relevante para el análisis que estoy realizando, y es que el pájaro no sólo es un ser que ha cantado en toda la tradición lírica, sino que ahora, además, otorga al poeta el instrumento de su voz una vez dejado el canto y hecho escritura: las plumas. Y a este respecto se puede hacer acopio de citas gongorinas en que la inmortalidad literaria se promete precisamente bajo la figura de la pluma prestada por el Fénix para garantizar una escritura inmortal ${ }^{38}$. Así, pues, las plumas de la fama han sido sustituidas por las del ave (aunque se trate de una rara avis), y su función ya no es el vuelo sino la escritura, que es otra manera de atravesar el tiempo y el espacio. En el fondo, lo que tenemos aquí es una forma poética de expresar la conciencia del paso de una poesía oral, que requiere la presencia física de emisor y receptor, a una poesía escrita en que tanto emisor como receptor quedan figurados en el encuentro que supone la escritura y su correlato la lectura.

Además de esto, encontramos un emblema que hace referencia al pájaro que se aposenta en una rama como imagen del camino que emprende cada uno en la vida una vez ha dejado la tutela de los padres, y simboliza ese buscarse un lugar y un camino propios ${ }^{39}$. Como ocurría con un aspec-

${ }^{38}$ Véase en especial el primer terceto del soneto en alabanza de la Historia de Felipe II escrita por Luis de Cabrera (266):

Plumas de un Fénix tal, y en vuestra mano,

¿qué tiempo podrá haber que las consuma,

y qué invidia ofenderos, sino en vano?

Sobre la misma idea está montado un segundo soneto dedicado a la misma ocasión (267).

${ }^{39}$ Se trata del emblema 35 de la primera centuria de Covarrubias. El mote es: «cada qual haga su nido» y en el dibujo se ve a unos pájaros que entran y salen de la copa de un árbol. Los versos dicen:

\footnotetext{
Después que vuestro hijo está criado

En religión y vida instituido,

debeisle despegar de vuestro lado,

Por más que de su madre sea querido:

Que el pajarito, viéndose emplumado

Se arroja del paterno y propio nido,

$\mathrm{Y}$ extendiendo sus alas por el viento,

En otra peña o árbol hace asiento.
} 
to de la imagen del gusano, se trata de una afirmación del «yo», y en este sentido, Góngora busca la alabanza para hacer su nido, establecer su independencia y su camino poético, y, curiosamente, con ello enlaza la imagen del peregrino, la última figuración del autor en el soneto.

Gracián ve prefigurado en el peregrino de este soneto al cantor y protagonista de las Soledades y del soberbio soneto: «De un caminante enfermo que se enamoró donde fue hospedado» (100), lo que quiere decir que Gracián, ya más cerca de nosotros que del momento en que tuvo lugar puntualmente la alabanza a que sirve el poema, lee el soneto como una pieza que habla de su propio autor y que constituye una auto-manifestación de Góngora. Pero aparte de esto, el peregrino es imagen habitual del hombre que hace su vida como si de un camino se tratara (homo viator). Aquí se aplicará, en particular, al camino poético, como aparece también en la relación que se establece al principio de las Soledades, en la dedicatoria al Duque de Béjar, en que los pasos del peregrino se confunden con los «pies métricos», no sólo en el famoso arranque: «Pasos de un peregrino son, errante, / cuantos me dictó versos dulce musa» ${ }^{40}$, sino especialmente en los versos 30-32, en que aparece además la imagen de votar la peregrinación a un noble:

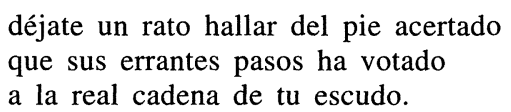

La relación del peregrino con la figura central del árbol no es en principio tan evidente como en los otros dos casos, lo que hace más relevante la aparición de esta imagen, por más artificiosa. El hacer que el caminante descanse a la sombra del árbol por una parte pone el soneto en relación con el mundo pastoril en que los pastores se recostaban a la sombra de los árboles para cantar (recuérdese el famoso inicio de la Égloga I de Virgilio: «Titire, tu patulae recubans sub tegmine fagi»), y por otra remite a la expresión figurada, muy pertinente aquí: «situarse a la sombra de alguien». El poeta, al igual que el gusano, se aprovechará de la alabanza misma para fortalecer su identidad y su poder. La imagen del peregrino conecta, además, con la idea que contenían las otras imágenes de la necesidad de la muerte como meta final para renacer, pues el hombre, en cuanto peregrino, tiene una sola meta, que es la muerte ${ }^{41}$. Según esto, Góngora

${ }^{40}$ Véase la esclarecedora relación que establece Joaquín Roses entre estos famosos versos y el «métrico llanto» del peregrino en la «Soledad Segunda» en su artículo, «Pasos, voces y oídos. El peregrino y el mar en las Soledades (II, vv. 112-89)», en $D a$ Góngora a Góngora, a cura di Giulia Poggi, Pisa, Edizioni ETS, 1998, pp. 181-195, en especial las pp. 189-191.

${ }^{41}$ El emblema 100 de la primera centuria de Covarrubias trata precisamente esta idea, lleva por lema «Sedem properamus ad unam» y muestra en el dibujo un sombrero, báculo 
entrega al destino final, que se debe entender como el templo de la fama, todo su camino poético.

Hago aquí un pequeño inciso para llamar la atención sobre otros poemas gongorinos en que la imagen del peregrino aparece como figura apelada, sobre todo en epitafios, alabanzas de casas, fincas, ciudades, etc. Habría que preguntarse, una vez desvelada la figura del peregrino como auto-figuración privilegiada de Góngora, si no habría que leer estos poemas a los que acabo de referirme, en cuanto a su estatuto comunicativo, como autorreflexivos, es decir, poemas en que el poeta se habla a sí mismo (y que en la poesía moderna derivarán en poemas directamente dirigidos a un tú que es el propio poeta) ${ }^{42}$.

Como resumen de este análisis, diré que Góngora consigue, mediante la maestría lingüística, mediante la coherencia y armonía de las imágenes, y mediante el poder transformador de éstas, que llevan el mundo de la enunciación a un plano simbólico, situar su enunciación no sólo de manera directa en la situación de alabanza concreta sino trascenderla y propiciar una lectura intemporal en que el poema habla de las condiciones generales de la alabanza y de toda poesía, y nos da muestra de su propio ser como poeta, caracterizándose a sí mismo. Como los símbolos repasados, todo en el poema mira en una doble dirección: la función pragmática concreta de alabanza y petición y la búsqueda de admiración por parte de un público general.

Se puede comparar este poema con otro escrito por Juan Rufo sobre el mismo personaje (parece que un tiempo después) para que quede más claro cuál es la clave del éxito del soneto de Góngora, por contraste:

\title{
A DON CRISTOBAL DE MORA, CONDE DE CASTILRODRIGO, CUANDO SU MAGESTAD LE HIZO SUMILLER DE CORS DE V. A.
}

\author{
Ya vas siendo retrato del primero: \\ en tronco firme estribas de justicia, \\ llevando al hombro la real primicia, \\ del gran Filipe imagen y heredero. \\ Ya triunfas de la invidia, monstro fiero; \\ ya arrastras por el suelo la malicia, \\ pues que tal majestad tienes propicia, \\ $y$ tanta parte en pecho tan entero.
}

\footnotetext{
y zapatos de peregrino y varios caminos que enlazan dos posadas, la de la vida y la de muerte (ésta última simbolizada por una calavera).

${ }^{42}$ Carreira (ed.), 168: «Oh tú cualquiera que entras, peregrino»; Carreira (ed.), 193 : «Oh peregrino, tú, cualquiera que llegas» (v. 12); Carreira (ed.), 220: «Madrid, oh peregrino, tú que pasas» (v. 2).
} 


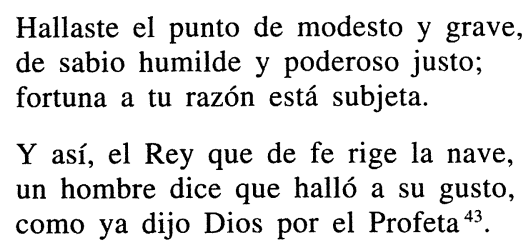

Este soneto está menos logrado que el de Góngora. Principalmente, le falta el virtuosismo de sostener durante todo el discurso una sola imagen que se desarrolle por amplificación, como hemos visto en Góngora. Con ello se pierde el fondo simbólico global que servía a Don Luis para producir un discurso que accedía a una interpretación simbólica y propiciaba la ampliación del marco enunciativo como superación de una circunstancia concreta, por no hablar de la consecuente pérdida de armonía totalizadora del soneto. Rufo intenta, en principio, un juego onomástico parecido al de Góngora, pero en lugar de usar el apellido, el jurado juega con el nombre: «Cristóbal» remite al santo que transportó a Cristo Niño como ahora Mora transporta la imagen del Príncipe. Pero este juego no pasa del primer cuarteto. En el segundo, parece haber un apunte hacia las hazañas de Hércules, debelador de monstruos, como Mora se enfrenta con la envidia y la malicia. El primer terceto es una alabanza directa, sin figuración alguna, y el último, el más interesante, parece que alude a un pasaje bíblico, según apunta Blecua ${ }^{44}$. La inconsecuencia de las comparaciones y el hecho de que la imagen del propio autor no aparezca de ninguna manera inscrita en el poema hace que la alabanza pierda interés y quede en una pieza puramente circunstancial, frente a la riqueza imaginativa y verbal de la de Góngora.

\section{HACIA UNA TEORÍA DE LA ENUNCIACIÓN CIRCUNSTANCIAL}

Al analizar el soneto gongorino he procurado poner en relación las estrategias que despliega con el resto de la obra del autor, aunque someramente. Con ello quería evidenciar la centralidad de este soneto en cuanto representante de los mecanismos comunicativos que están en la base de toda la obra del poeta y, en general, de todo poema lírico. La elección de un poema de circunstancia es aleccionador por cuanto nos muestra que toda enunciación histórica (y un poema lo es), si se inscribe como escritura y como escritura con vocación de trascenderse, se hace legible y funcional en cualquier tiempo y lugar con más o menos éxito. En consecuencia, me

\footnotetext{
${ }^{43}$ Juan RUFO, Las seiscientas apotegmas y otras obras en verso, ed. Alberto Blecua, Madrid, Espasa-Calpe, 1972, p. 344.

${ }^{44}$ "Quizá alude a Daniel, 2, 25: 'Inveni hominem de filiis transmigrationis Juda, qui solutionem regi annuntiet'».
} 
propongo ahora, y a raíz de las conclusiones que ha arrojado este análisis, establecer unos parámetros teóricos en que instalar nuestra discusión sobre la poesía circunstancial.

A pesar de la afirmación de Goethe a propósito de que toda poesía es de circunstancias, ha habido en general desde el romanticismo un rechazo a este tipo de poemas celebrativos y portadores de una funcionalidad pragmática, como hemos detectado, sin ir más lejos, en la lectura que Jammes hace de esta parte de la obra de Góngora. Me parece particularmente interesante la postura de Karlheinz Stierle porque sienta las bases para un estudio de la identidad del género «lírica» que le llevan al rechazo (o quizá sería mejor decir: parten del rechazo) de la poesía de circunstancias como perteneciente al género de la lírica ${ }^{45}$. Para cualquiera que lea el trabajo del alemán queda claro que su punto de arranque es una concepción predefinida y romántica del género, y a ella dedica su teoría de la falta de identidad de la lírica y de los sujetos implicados en el tipo de comunicación que ella establece.

La problemática identidad del género discursivo que plantea Stierle no es para mí más que una consecuencia de la problematicidad de la identidad discursiva inherente a cualquier texto escrito, según apunta el propio autor. Stierle parte de que un texto (en cuanto señal, objeto físico que es el soporte de la comunicación) sólo puede tener coherencia, pues la identidad únicamente existe (o no) en tanto que ese texto se convierte en acto, esto es, en discurso. La coherencia es una característica textual mientras que la identidad lo es discursiva. Ahora bien, todo texto escrito sufre una pérdida de identidad por dos razones: porque no ocurre (normalmente) de una sola tirada (si es lícito expresarse así), uno contextu, como Stierle dice, recogiendo una fórmula del derecho romano; y porque su identidad límite la marca un tipo de discurso social de carácter ideal que, de manera abstracta, asigna el contexto, los papeles de los participantes y el sentido del discurso en cuestión. Toda realización discursiva histórica queda, por supuesto, por debajo de esa identidad ideal, y en consecuencia contagia de su falta de identidad a los papeles de los participantes (en especial el sujeto emisor) que son funciones del texto (y no a la inversa).

Esto está claro desde el momento en que en la recepción de un escrito no accedemos directamente a la persona del emisor sino que su identidad debe ser reconstruida a partir de nuestra lectura del texto, y, en consecuencia, se puede decir que toda identidad de un emisor por escrito es una identidad construida ${ }^{46}$. Sin embargo, ocurre que en los discursos que tie-

\footnotetext{
${ }^{45}$ Karlheinz StIERLE, «Lenguaje e identidad del poema. El ejemplo de Hölderlin», en Fernando CABO ASEguinolazA (ed.), Teorías sobre la Lírica, Madrid, Arco Libros, 1999, pp. 203-268

${ }_{46}$ Se trata de la distinción ya apuntada entre emisor y fuente. En la escritura lo que tenemos en primera instancia es una imagen de la fuente, que puede coincidir o no, y
} 
nen, por su funcionalidad, un fuerte anclaje pragmático, el contexto permite detener en alguna medida la deriva y pérdida de identidades y dota de cierta unidad al sentido y condiciones del discurso. Sin embargo, el discurso literario no está, en principio, sometido a una funcionalidad pragmática precisa, lo que hace que su identidad sea más problemática, fenómeno que aparece multiplicado en la poesía, ya que si la narrativa y el drama alcanzan cierto grado de identidad porque se sirven, como base, de géneros discursivos distintivos en el ámbito social (relato y diálogo), la poesía, sin embargo, puede tomar la forma de cualquier discurso social para parodiarlo: puede ser una oración, una felicitación, agradecimiento, etc., lo que la convierte en el anti-discurso por excelencia, negando así toda identidad al sujeto enunciador, en tanto que función suya.

En esto Stierle viene a coincidir con J.-M. Schaeffer que reconoce que la poesía puede poner en funcionamiento cualquier modalidad enunciativa $\mathrm{y}$, por tanto, es inmune a la determinación por un criterio pragmático unitario ${ }^{47}$. Pero eso no hace que en un determinado momento histórico no nos podamos referir a un conjunto de textos como líricos. Y de hecho, la poesía suele hacer referencia a sí misma, cosa que no ocurriría si fuera un discurso sin ninguna identidad. Esta autorreferencia se centrará principalmente en su aspecto formal y se aludirá a «versos» o «soneto», como hace Góngora en el soneto «Al excelentísimo señor el Conde-Duque» (391), cuando dice «los números, señor, de este soneto / lenguas sean, y lágrimas no en vano», y ello constituye una pista sobre lo que el propio poema considera la base de su identidad ${ }^{48}$. Pues, en efecto, la poesía lírica no puede alcanzar identidad discursiva como género literario, en tanto que es capaz de albergar en su propia enunciación una diversidad de discursos sociales claramente no-literarios, lo que lleva a Stierle a rechazar la poesía de circunstancia como perteneciente a la lírica, quedándose con el tipo de lírica más intimista y monológica, que tematiza su propia búsqueda de

en diversos grados con el emisor real. Por otra parte, la construcción de imágenes de los participantes no es privativa de la comunicación escrita. En el medio oral inevitablemente nos dirigimòs a una imagen de nuestro interlocutor, y más si es la primera vez que le hablamos. Nos vamos construyendo una imagen suya conforme avanza la comunicación.

47 Jean-Marie SCHAEFFER, Qu'est-ce qu'un genre littéraire?, Paris, Seuil, 1989, pp. 85-86: «Le vaste continent qu'on regroupe sous le nom de 'poésie lyrique' réalise quant à lui tous les cas de figures possibles: énonciateur réel, énonciateur fictif, énonciateur feint, énonciation sérieuse, énonciation ludique, énonciateur ludique-fictive. Autant dire qu'il est inerte par rapport à la diversité énonciative, ce qui est une des raisons de la dificulté qu'on rencontre lorsqu'on veut le corréler à ses faux frères que sont la poésie épique et la poésie dramatique, toutes deux liées plus ou moins fortement à des spécificités énonciatives».

${ }^{48}$ Schaeffer trae a colación también la autorreferencia: «La nomination générique possède partiellement un caractère autoréférentiel, en ce sens qu'elle implique une composante décisionnelle» (op. cit., p. 127). 
identidad. Alega el autor alemán que la poesía de circunstancias no se puede considerar tal porque está anclada en un marco pragmático fijado que la hace funcionar de manera muy parecida a otros discursos sociales. Pero el problema estriba, como ya he apuntado, en que Stierle busca la identidad de la lírica donde no la puede encontrar, en el nivel enunciativo.

Ha sido Kate Hamburger quien ha defendido, en posición diametralmente opuesta a la de Stierle, que la lírica, frente a los géneros constitutivamente ficticios como la narrativa en tercera persona y el drama, constituye un enunciado de realidad, pero no actúa en un contexto de realidad. El poeta se sitúa como tal «yo» lírico que atrae hasta el polo de la subjetividad todo aquello que canta, mientras que en un discurso que funciona en un contexto de realidad lo que interesa es el polo-objeto ${ }^{49}$. Ahora creo que podemos reformular esta propuesta a la vista de lo estudiado de la siguiente manera: no es la actuación del «yo» la que se vuelca sobre el polo de la subjetividad sino que es nuestra lectura la que hace que, una vez despegados del marco pragmático real, nos volquemos en el lado más subjetivo o subjetivicemos la enunciación, como hemos visto que sucede aquí con este poema de Góngora. Y esto no ocurre desde luego por capricho nuestro, sino que nuestra lectura es correlato de un proceso de escritura que, al instalarse en el terreno público y como tal escritura, supone una ruptura inicial del marco pragmático de interpretación abriéndose a lecturas posteriores y anticipándolas como no-funcionales para el contexto inicial, pero relevantes en todos lo contextos posibles; y permite también al autor tomar diversas máscaras enunciativas, como aquí ocurre con la trasformación de Góngora en las imágenes de pájaro, gusano y peregrino. Se puede decir que en la época de Góngora, para sus contemporáneos, emisor y fuente coincidían plenamente, y ellos podían leer el poema como texto de una petición auténtica (que incluye una alabanza) y como obra de arte de ese género. Para nosotros, sin embargo, tiene más importancia el juego que el emisor realiza con la multiplicación de las fuentes enunciativas, y que permiten situar la alabanza y petición en un segundo plano, accediendo directamente a un plano imaginativo, que junto con la perfección formal del poema, dejan inscrita la comunicación en el lugar indeterminado de la lectura, que puede coincidir con el momento de alabanza concreta y con cualquier otro momento.

\footnotetext{
${ }^{49}$ Käte Hamburger, Logique des genres littéraires, Paris, Seuil, 1986, p. 220: «Ces énonciations se sont pour ainsi dire retirées du pôle-objet, se sont restructurées l'une par rapport 'a l'autre et ont ainsi pris pour thèmes des contenus qui ne se rapportent pas, en tout cas pas directement, au complexe-objet. Elles ne sont ni orientées dans sa direction ni gouvernées par lui. Elles ne forment pas un 'complex-objet', c'est-à-dire, un complexe du type communicationnel, mais quelque chose d'autre que nous définissons comme un 'complexe de sens' (Sinnzusammenhang). Cela veut dire que les énonciations ont quitté le pôle -objet pour pénétrer dans la sphère du pôle-sujet. C'est bien ce processus qui engendre l'oeuvre d'art lyrique».
} 
Creo, en definitiva, que habría que eliminar la noción de contexto real que usa Hamburger y dejar de hablar de que la poesía funciona o no funciona en un marco pragmático fijado, porque la noción de contexto pragmático es engañosa en este sentido. En primer lugar, conviene señalar cómo la teoría de la relevancia ha demostrado que todo enunciado debe activar el contexto en que debe ser entendido, entre otras cosas porque la labor de descipción de un marco pragmático real es imposible por cuanto supone especificaciones prolongables hasta el infinito ${ }^{50}$. Pero hay otra razón más poderosa, y es que el marco pragmático, según hemos visto, no está de ninguna manera fijado desde el momento en que la poesía se hace un discurso escrito y público. La apertura hacia una recepción general anula cualquier intento de determinar un marco pragmático por muy pragmática que sea la actividad comunicativa que se pretende realizar con tal poema.

El rasgo identificador de la poesía lírica, y que permite aunar todas sus manifestaciones bajo una sola etiqueta, no puede ser, entonces, más que formal (en el sentido amplio), ya que el carácter de escrito público lo comparte con infinidad de géneros distintos ${ }^{51}$. Por criterios formales apunto aquí brevemente algunos, ya que el tema pide una investigación posterior: el primero es la brevedad, el segundo (y casi consecuencia del anterior) es la intensidad significativa. El hecho de estar en verso fue determinante en un periodo histórico, pero este criterio puede sustituirse por el de la intensidad significativa y brevedad, como muestra el poema en prosa $^{52}$.

- Por muy extraño que nos pueda parecer esta propuesta ahora, quiero dejar claro que se trataba de una obviedad para los autores y lectores de los siglos XVI y XVII que no consideraban la lírica como un género unitario sino precisamente como el conjunto de todas esas piezas breves que

${ }^{50}$ SPERBER, D. \& Wilson, D., Relevance: Communication and Cognition, Oxford, Blackwell, 1995, pp. 132 y ss.

${ }^{51}$ A esta misma conclusión llega Frantisek Miko en «Verso un modello della comunicazione letteraria»: "L'attributo 'letterario' è una qualificazione stilistica, il che significa che il fenomeno di cui stiamo parlando deve essere interpretato a livello stilistico. Tutto il letterario è stilistico», en Carlo Prevignano (ed.), La semiotica nei paesi slavi. Programmi, problemi, analisi, Milano, Feltrinelli, 1979, p. 515.

${ }_{52}$ Gérard Genette parece coincidir con este punto de vista en su artículo «Langage poétique, poétique du langage» (Figures II, Paris, Seuil, 1969, pp. 123-153). Empieza señalando ahí que todos los rasgos formales de la poesía del periodo clásico eran opcionales excepto el que constituía la esencia de la poesía: el respeto a la forma métrica, y después de hacer una inteligente crítica a la teoría de Jean Cohen acaba definiendo la esencia del discurso poético, con Eluard, como la aparición de la «evidencia poética», que es un estado, y que se rodea de un margen de silencio, que puede ser (interpreto) bien el de las pausas versales (y su representación gráfica en el blanco de la página) bien el de lo que queda más allá de la necesaria brevedad (por superfluo o porque no tiene acceso directo a través del lenguaje). Esto dará una idea de lo que quiero que se entienda cuando hablo de «intensidad significativa». 
aludían a circunstancias concretas como bodas, natalicios, llantos fúnebres, etc... Fíjese, por ejemplo, que Scalígero define la materia del subgénero «lírica» como: «Quaecumque in breve Poema cadere possunt, ea Lyricis numeris colligere ius esse. Laudes, amores, iurgia, insectationes, comessatioria, obiurgatoria, vota, ad indulgendum genio exhortationes. Contra, sobrietatis, commendationes, gestorum summarias explicationes, desideria, conquestiones, locorum, temporum, explicationes, nova consilia, deliberationes, negotiorum susceptiones, susceptorum repudiationes, invitationes, repulsiones, dehortationes, detestationes et alia siqua sunt» ${ }^{53}$. Esta definición nos muestra, por una parte, que el criterio temático incluye una miscelánea no sólo de temas sino de actos de habla diversos, y por otra que la determinación de la lírica es puramente formal, pues no se trata de que los poemas sean esencialmente líricos sino de que los contenidos mentados se traten en «metros líricos». A su vez, esta categoría está al mismo nivel que toda una serie de subgéneros perfectamente definidos por su contenido, entre los que se cuentan: epithalamion, genethliacum, soteria, propempticon, parenético, nuthético, paramythetico, epibaterion, apobaterion, paideuteria, panegírico, laus, hymni, evocatorii, peanes, ditirambos, epitafio, consolatio, elegía, epigrama..., y dejo otros sin nombrar. Se trata, en general, de poemas pensados para determinadas circunstancias y ocasiones en la vida, y los únicos criterios que pueden encontrar para reclamar su identidad frente a los demás géneros son puramente negativos: no ser poemas largos y ocuparse de las actividades sociales que no trataban (en exclusiva) los poemas extensos.

Quiero acabar haciendo una reflexión, a propósito del poema con el que empezaba, sobre lo que se entiende por sinceridad poética y su relación con los enunciados pragmáticos funcionales. Jammes tiende a confundir sinceridad poética con sinceridad de conciencia, cuando se trata de dos categorías que nada tienen que ver una con otra, como se ve cuando distingue, para evitar la etiqueta de «poesía de circunstancias», entre poemas sinceros o no sinceros, o en su terminología «poesía de corte» / "poesía personal» ${ }^{54}$. Como dice Hamburger el «yo» que sueña o fantasea es tan sincero como el yo que cuenta una experiencia realmente vivida ${ }^{55}$. Por eso, no tiene sentido plantearse, como hace Jammes, si hubo traición por parte de Góngora cuando años después, en el panegírico del duque de Lerma, trata a Cristóbal de Mora (entre otros) como uno de los sátrapas que aca-

\footnotetext{
53 Julio César EsCALÍGero, Poetices libri septem, Lyon, 1561,Libro III, cap. CXXIIII, p. 169.

${ }^{54}$ Op. cit., pp. 257-258.

${ }^{55}$ HAMBURGER, op. cit., p. 242: «De même, le mesonge ou le rêve racontés à quelqu'un sont le champ d'expérience du Je menteur ou rêveur, à cette réserve près de quand il ne s'agit pas de littérature nous sommes en droit, puisque les énoncés en question sont présentés, comme valant pour une réalité, d'en soumettre le contenu à vérification».
} 
paraban injustamente el gobierno bajo el reinado de Felipe II: «celante altera el judicioso terno / de los sátrapas ya de aquel gobierno» (313, vv. 159$160)^{56}$. La poesía de elogio o cortesana no puede ser sincera o insincera, sentida o no, ya que se sitúa en unas coordenadas enunciativas en que la sinceridad de conciencia queda cancelada. Esto viene ejemplificado perfectamente por el uso de la hipérbole, otro de los escollos con que choca Jammes en su rechazo a la poesía cortesana. Cuando Góngora promete la tiara papal a todos los obispos que canta o cuando considera a su amigo un nuevo Garcilaso (Soneto «A don Luis de Vargas») (67) está utilizando la misma estrategia que cuando compara al rey con el Fénix. El lector entiende inmediatamente que el enunciado no es literal, y la aparición de la hipérbole es un índice preciso para avisar al lector del género ante el que se encuentra: el elogio. Se puede afirmar, incluso, que la sinceridad del género requiere el uso de una figura que es prototipo de falta de sinceridad, pues en definitiva lo que cuenta es la expectativa de los lectores, y el gesto de honradez para con ellos es ser hiperbólico en los elogios. El escándalo que supone para Jammes el prometer la tiara papal a un obispo ya provecto sólo se entiende en una concepción de la poesía post-romántica que confunde sinceridad vital y valor poético: « ¿Cómo podemos imaginar que Góngora haya podido, por ejemplo, pensar un solo momento que Mardones tuviese alguna probabilidad de llegar a ser papa en 1615, cuando sabemos de otras fuentes que este prelado tenía en aquel momento 87 años, ya que había nacido en 1528 !» ${ }^{57}$. Pero Jammes no cuenta con que Mardones aspira todavía al papado incluso cuatro siglos después, porque esa intención y el propio obispo viven aún en un soneto de Góngora.

\footnotetext{
${ }^{56}$ Jammes insiste en la descalificación que Góngora atribuye a Mora en el Panegírico para reforzar su idea del poco valor del soneto ya que técnicamente tiene que reconocer su maestría: «Es cierto que desde el punto de vista técnico el soneto está admirablemente construido (...). Pero si lo comparamos con las poesías satíricas o burlescas, indiscutiblemente más sinceras, que don Luis escribió durante el mismo viaje (...) o con la palinodia del Panegírico (...) no podemos compartir la admiración de Salcedo», pp. 219-220. Y: «Entre estos tres 'sátrapas' o 'triunviros' (bastante ciegos por oponerse a los designios de la Providencia, bastante déspotas por pretender concentrar todo el poder entre sus manos, signo de 'barbarie' manifiesta, y bastante incompetentes por dejar completamente vacías las arcas del Estado) se encontraba Cristóbal de Moura, a quien Góngora había dedicado en 1593 un soneto muy obsequioso, primer paso de su carrera como pretendiente» (p. 249).

${ }^{57}$ JAMMES, op. cit., p. 217.
} 


\title{
RESUMEN
}

¿Es un soneto de Góngora también una alabanza?, por Ángel Luis Luján Atienza.

El artículo cuestiona la identidad de la lírica como género literario. Para ello se lleva a cabo un estudio de la poesía llamada de circunstancias en dos fases. En un primer momento se analiza con detenimiento el primer soneto cortesano de Góngora «A Don Cristóbal de Mora» (1593), y se muestra cómo, desde el punto de vista enunciativo, este poema funciona simultáneamente como discurso literario y como discurso pragmático de alabanza-petición de favor. En segundo lugar, se establece, a partir de las conclusiones del análisis, un marco teórico para demostrar que la lírica alberga una infinidad de discursos que funcionan en contextos de enunciación real y cuyo carácter literario le viene dado por rasgos formales, en el sentido más amplio.

Palabras clave: Pragmática de la poesía. Luis de Góngora. Emblemática y literatura.

\begin{abstract}
This paper calls the identity of lyrical poetry as literary genre into question, starting from a study of the circumstantial poetry. Firstly, an analysis of the first courtly sonnet by Góngora: «A Don Cristóbal de Mora» (1593) shows that the poem is at the same time a literary discourse and a pragmatic one (in order to get the noble's favour). Secondly, a theoretical approach to this problem tries to conclude that the literary genre of lyric contains infinity of texts acting in actual contexts, whose literary quality arises from formal (in the widest sense) features.
\end{abstract}

Key words: Pragmatics of poetry. Luis de Góngora. Emblematical literature. 